\title{
Parrot Ownership and Capture in Coastal Ecuador: Developing a Trapping Pressure Index
}

\author{
Rebecca Biddle ${ }^{1, *(D)}$, Ivette Solis-Ponce ${ }^{1}$, Martin Jones ${ }^{2}$, Mark Pilgrim ${ }^{1}$ and Stuart Marsden ${ }^{2}$ \\ 1 The North of England Zoological Society, Upton, Chester CH2 1LH, UK; ivisolisponce@gmail.com (I.S.-P.); \\ m.pilgrim@chesterzoo.org (M.P.) \\ 2 Department of Natural Sciences, Manchester Metropolitan University, Manchester M15 6BH, UK; \\ m.jones@mmu.ac.uk (M.J.); S.Marsden@mmu.ac.uk (S.M.) \\ * Correspondence: b.biddle@chesterzoo.org; Tel.: +44-124-438-9729 or +44-739-551-4945
}

Citation: Biddle, R.; Solis-Ponce, I.; Jones, M.; Pilgrim, M.; Marsden, S. Parrot Ownership and Capture in Coastal Ecuador: Developing a Trapping Pressure Index. Diversity 2021, 13, 15. https://doi.org/ 10.3390/d13010015

Received: 25 November 2020 Accepted: 21 December 2020 Published: 5 January 2021

Publisher's Note: MDPI stays neutral with regard to jurisdictional clai$\mathrm{ms}$ in published maps and institutional affiliations.

Copyright: () 2021 by the authors. Licensee MDPI, Basel, Switzerland. This article is an open access article distributed under the terms and conditions of the Creative Commons Attribution (CC BY) license (https:// creativecommons.org/licenses/by/ $4.0 /)$.

\begin{abstract}
We located rural communities with pet parrots and used these locations to predict the probability of illegal parrot ownership across coastal Ecuador, using variables related to demand for pets, parrot availability, and trapping accessibility. In 12 pet keeping communities, we carried out in-depth interviews with 106 people, to quantify ownership, trapping, and interviewees' attitudes towards these behaviours. We combined these data to calculate a trapping pressure index for four key roosting, feeding and nesting sites for the Critically Endangered Lilacine or Ecuadorian Amazon Parrot Amazona lilacina. We found that $66 \%$ of all communities had pet parrots and $31 \%$ had pet Lilacines. Our predictive models showed that pet parrot ownership occurs throughout coastal Ecuador, but ownership of Lilacines by rural communities, is more likely to occur within the natural distribution of the species. The number of people per community who had owned Lilacines in the last three years varied from $0-50 \%$, as did the number of people who had trapped them-from $0-26 \%$. We interviewed 10 people who had captured the species in the last three years who reported motives of either to sell or keep birds as pets. Attitudes towards pet keeping and trapping differed among the 12 communities: $20-52 \%$ believed it was acceptable to keep pet parrots, and for $32-74 \%$, it was acceptable to catch parrots to sell. This being said, most people believed that wild parrots were important for nature and that local people had a responsibility to protect them. We conclude that trapping pressure is greatest in the southern part of the Lilacine's range, and urgent conservation measures such as nest and roost protection, and local community engagement are needed.
\end{abstract}

Keywords: Amazona lilacina; poaching; conservation threats; mangrove; dry forest; local knowledge; attitudes; Lilacine Amazon

\section{Introduction}

Parrots (Psittaciformes) are among the most endangered and rapidly declining bird groups, with $28 \%$ of their species classified as threatened [1]. Globally, over a third of parrot species are caught to fulfil the demand of the international wildlife trade [1-3]. In the Neotropics, over half of the studied parrot populations are in decline [4], and one reason for this is the high demand for the pet trade [5]. Neotropical species are particularly favoured as pets $[2,6]$, and it is suggested that trapping is a stronger threat to their conservation than habitat loss [7]. Amazon parrots and macaws are preferred due to their attractiveness and ability to mimic the human voice [8]; this is illustrated in Costa Rica, where nearly 20\% of households have a pet parrot and half of these are Amazona species [9]. Consequently, the rate at which Amazon parrots and macaws are trapped is much higher than expected considering their availability in the wild [10].

Trapping risk is highest where parrots are abundant in the wild, where demand is high and where parrots are relatively easy to catch and sell [11]; therefore, trapping pressure may differ across a species' range and also between species. Additional factors found to drive hunting and trapping include overlap with human population [11,12] and proximity to 
infrastructure or towns [13]. Attitudes and subjective norms are also factors that influence decision making [14], and are therefore likely to affect the level of pet keeping and capture in different areas. In Ecuador, wild bird keeping is illegal [15], and whilst ownership appears to be declining in major cities [16] demand is still high in rural areas, where over half of coastal communities still keep pet parrots [17]. The most frequently reported confiscated bird species in the country are those with wild distributions exclusive to this coastal region [16,18]. Moreover, this region is one of the most densely populated and impoverished [19] parts of Ecuador, the habitats here have been drastically reduced [20] and are greatly underrepresented in the country's national protected areas system [21].

The Critically Endangered Lilacine or Ecuadorian Amazon Amazona lilacina, a species recently split from the A. autumnalis group, is found exclusively within the coastal region of Ecuador [22]. CITES reported thousands of individuals of this species being trapped and exported in the early 1980s [23] and although frequency of trapping is likely to have reduced significantly in recent years, there are still multiple reports of capture and petkeeping within rural communities [17]. An average of 392 wild-caught parrots, including 30 A. autumnalis, were confiscated annually in Ecuador between 2003 and 2016 [16]. Although some of these may be older birds, and they may be either A. lilacina or A. a. salvini, this figure suggests that some level of trapping is still occurring to fulfil the demand for pets. The goal of this study was to understand the risk of trapping in rural communities and formulate a strategy for conservation support. Specific objectives were:

1. Locate communities with pet parrots by conducting surveys across coastal Ecuador, and use these locations to predict the distribution of pet parrots, and the likelihood of local parrot trapping, using variables related to parrot availability, opportunity and demand;

2. Within communities that keep pet parrots, interview local people to quantify the level of parrot ownership, trapping and the attitudes towards these behaviours;

3. Develop a trapping pressure index based on model predictions, locally reported incidence and attitudes towards parrot capture and ownership.

\section{Materials and Methods}

\subsection{Surveys to Locate Communities with Pet Parrots}

In order to locate rural communities with pet parrots, we conducted surveys between January and July 2017. The study area encompassed the extent of occurrence of the Lilacine Amazon Amazona lilacina and communities close $(<10 \mathrm{~km})$ to forest patches, where wild parrots may occur were selected. Participants were asked to confirm if they knew of pet parrots in their community, and if possible to identify the species. Prior verbal consent was obtained from each participant and full ethical approval of survey content and methods was gained from The North of England Zoological Ethical Review Committee. We aimed to survey at least four households per community; however, some communities were made up of just a few houses, so this was not always possible. We recorded the geographic coordinates of communities with all pets, pet parrots and pet Lilacines, and calculated how many communities each species was recorded in. We used IUCN Red List range maps provided by BirdLife International [24] in order to determine if species were native to the study area. Range maps are frequently updated so we report the year of update for each range map in the results. ArcGIS (version 10.8.1) [25] was used, clipping the distribution shape files, to calculate the size of each species range within our study area.

It is illegal to keep native bird species as pets in Ecuador [15], yet in our experience, people speak openly about their parrots and are proud to show them off. However, it was important that participants did not feel threatened or that we were collecting information to inform the authorities. Therefore, surveys were conducted by a local Ecuadorian researcher, in Spanish, with only the researcher and interviewee present, and it was made clear that all information given was anonymous, and only to be used for scientific research.

Although we refer to A. lilacina as the Lilacine or Ecuadorian Amazon Parrot, neither of these common names have Spanish translations that are used in Ecuador. Most local 
communities refer to "loro frentirrojo" (Red-lored Parrot), which in English describes the A. autumnalis group and includes $A$. a. salvini in northern Ecuador. To avoid confusion, we use A. lilacina in our communication with local communities and use photographs to confirm identity, but refer to the Lilacine Amazon in this manuscript.

\subsection{Distribution Models to Predict Parrot Ownership}

From our surveys we created two groups of geographic coordinates to represent (1) communities with pet parrots, and (2) communities with pet Lilacines. The MaxEnt package in $\mathrm{R}$ (version 4.0.3) [26,27] was used to build distribution models based on these coordinates combined with random background points within $30 \mathrm{~km}$ buffers of community locations, to predict the distribution of pet parrots, and the distribution of pet Lilacines. Variables were extracted to match each corresponding location and were chosen due to their influence over parrot ownership and trapping [11]: opportunity (presence of parrots and their desirability); demand (presence of people and the infrastructure for trade); and accessibility (into the forest).

For each location, we calculated a "species value" to represent parrot trapping opportunity. For the pet model, this was calculated based on the presence of wild parrot species at that location using species range maps [24], combined with the frequency of the species being reported as a pet; 0.1 was allocated for each species present in that area, and an additional 0.1 was added if that species was reported in a single community, 0.2 if in two communities, etc. This value was used just for comparative purposes within the study and we gave equal weighting to wild species presence and popularity in captivity, as we had no evidence that either was more important than the other. For the pet Lilacine model, this value was replaced with the predicted occupancy area from our distribution models created using observations of the wild population [28]. For both models, we also used the estimated human population [29], the Euclidean distance to the nearest town and nearest road calculated in ArcGIS using OpenStreetMap [30] data, and the mean annual Normalised Difference Vegetation Index (NDVI) from the monthly MODIS product over 2010-2015 as a proxy of vegetation cover.

For each group of points, spatial autocorrelation was controlled for by limiting them to one per $1 \mathrm{~km}$ using the R package spThin [31]. Predictors were checked for pairwise correlation across random points within the study area, using pair plot for collinearity [32]. Model evaluation was performed with five-fold cross validation and the mean AUC + / $\mathrm{SD}$ are presented to demonstrate the predictive ability. An AUC of 0.7 means there is a $70 \%$ chance that the fitted model will be able to correctly distinguish between presence and absence [33]. All data were included in the final models. We present the permutation importance (\%) of variables, with a high value indicating that the final model depends heavily on that variable [27].

\subsection{Interviews to Quantify Parrot Ownership, Trapping and Attitudes}

We selected 12 communities where pet parrots were present to conduct interviews with community members about their experiences and attitudes towards parrot ownership and capture. These communities ranged in size from 50 to 300 people. The reason these sites were chosen was because our focus was on understanding risk to Lilacine Amazons, so the selected communities fell within the species extent of occurrence and were $<15 \mathrm{~km}$ away from key roosting, nesting and feeding grounds [17]. These 12 communities were grouped into four clusters (Figure 1). We interviewed at least six participants from different households in each community. Participants were outdoor workers (i.e., agriculturalists, fishers and crab fishers) selected for their familiarity with parrots in their local area. The same methods regarding informed consent and data anonymity as described in Section 2.1 were followed. Due to low literacy levels amongst participants, all questions were read out aloud and the answer provided was recorded by the researcher. Age and gender of each participant was recorded. The interview consisted of eight questions and seven attitude statements arranged on a five point symmetric Likert scale (Table 1). The Likert 
package [34] in $\mathrm{R}$ (version 4.0.3) [26] was used to visualise attitude statements. Responses were grouped into positive, neutral or negative and a non-parametric test (Kruskal-Wallis) was used to determine significant differences in responses between the four community clusters.

Table 1. Interviews about parrot ownership and capture asking eight questions and seven attitude statements, which were read out aloud by the researcher in Spanish. Interviews were anonymous and participants could decline to answer any questions.

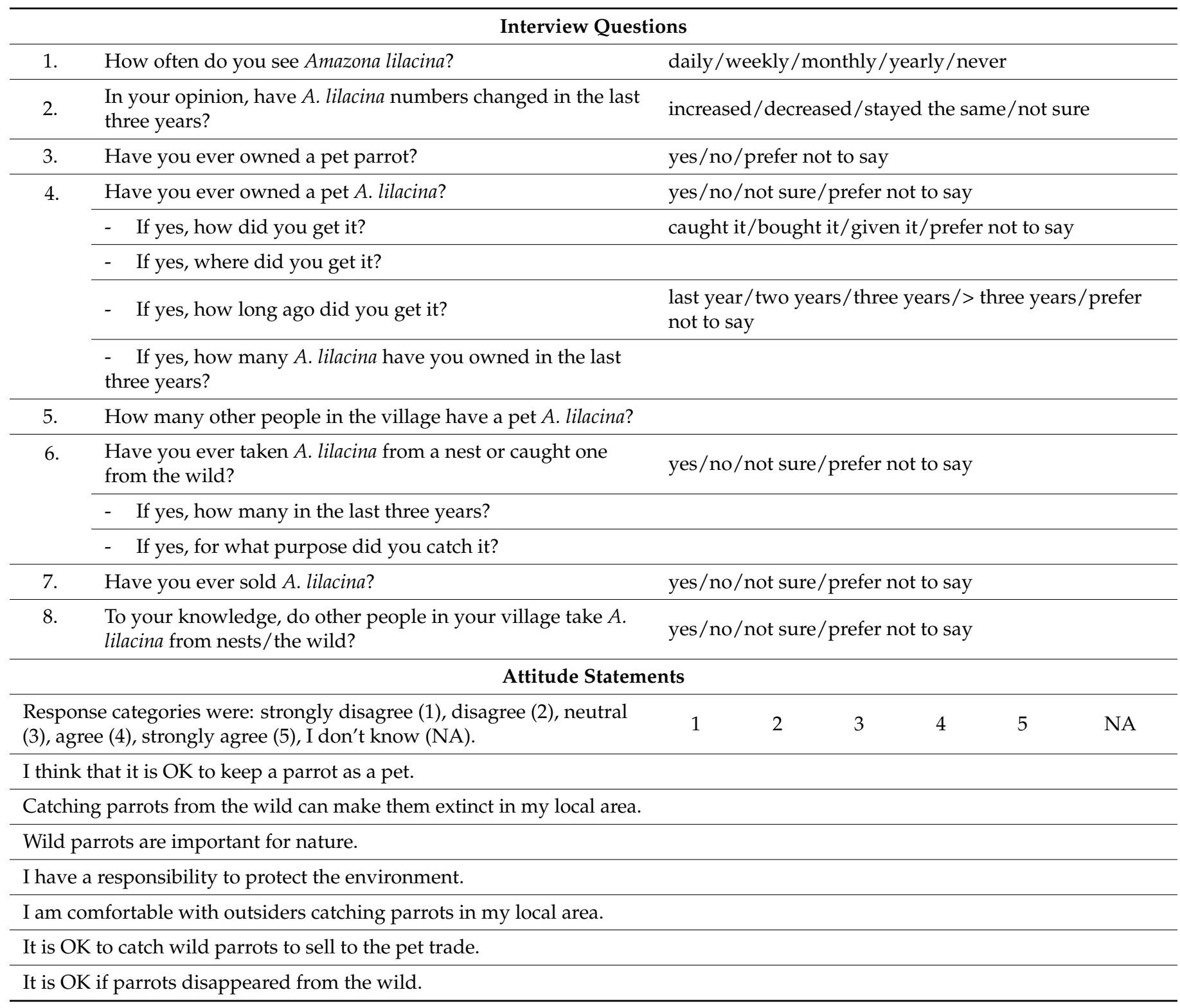




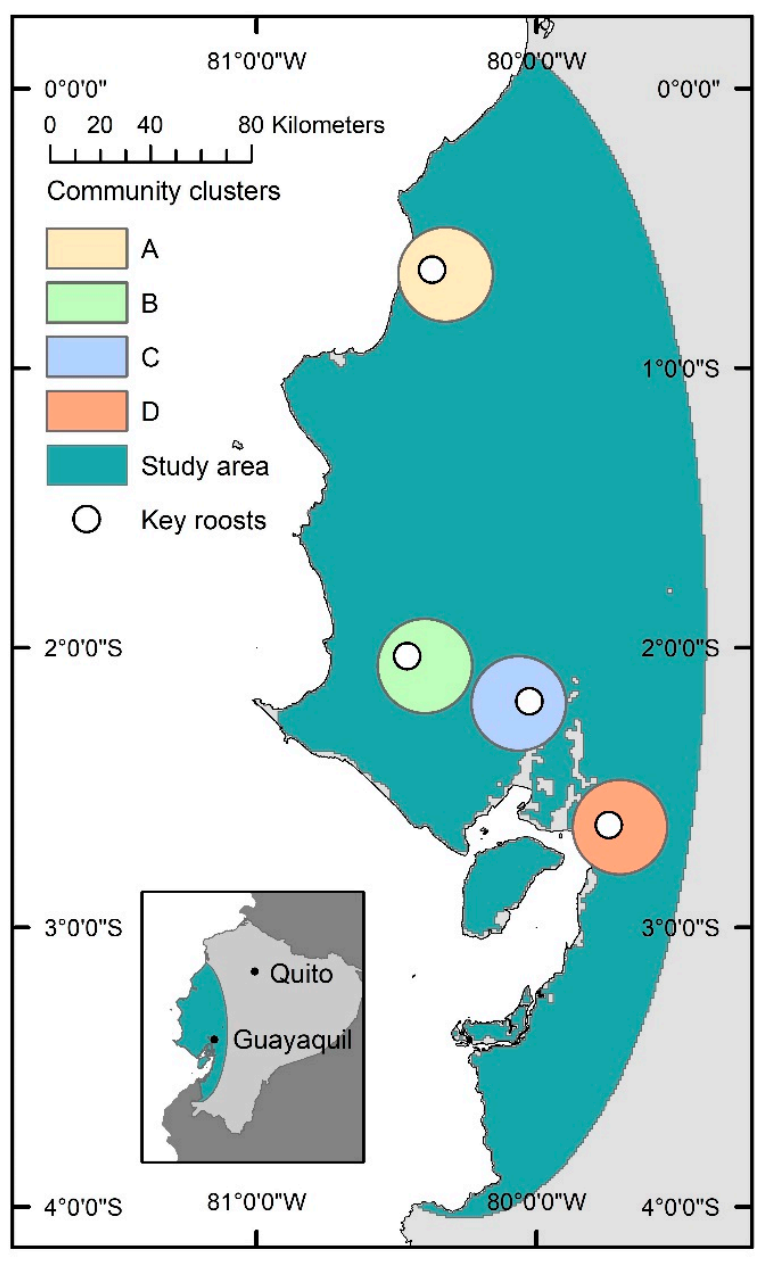

Figure 1. Interviews about parrot ownership and capture were conducted in 12 communities, grouped into four clusters (A, B, C, and D) near key Lilacine Amazon roost sites. Each cluster contains three communities $<10 \mathrm{~km}$ apart.

\subsection{Trapping Pressure Index}

To prioritise areas for conservation support, we calculated a trapping pressure value for each of the four community clusters, to represent the level of risk to the wild Lilacine Amazon population from capture and local desire for pet keeping. This risk value was calculated by combining the following six factors: (1) the mean model value for pet parrot keeping (which represents a probability that pets occur at that location); (2) the mean model value for pet Lilacine keeping; (3) the percentage of people who have owned a pet Lilacine in the last three years; (4) the percentage who have trapped Lilacines in the last three years; (5) the percentage of people who think it is OK to keep a parrot as a pet; and (6) the percentage who think it is OK to catch wild parrots to sell.

\section{Results}

\subsection{Locations and Species of Pet Parrots}

Surveys were carried out in 65 communities (mean $=6$ interviewed people per community; range 3-20). In $43(66 \%)$, pet parrots were confirmed, and in $20(31 \%)$, pet Lilacines were confirmed. Of the 19 wild parrot species, nine were reported in at least one community, with the most frequently reported being Lilacine Amazons (Figure 2) and Grey-cheeked Parakeets Brotogeris pyrrhoptera. The mean range size within the study area of parrots found as pets was $27,370 \mathrm{~km}^{2}$, compared to $8677 \mathrm{~km}^{2}$ for those not kept as pets (Table 2). 


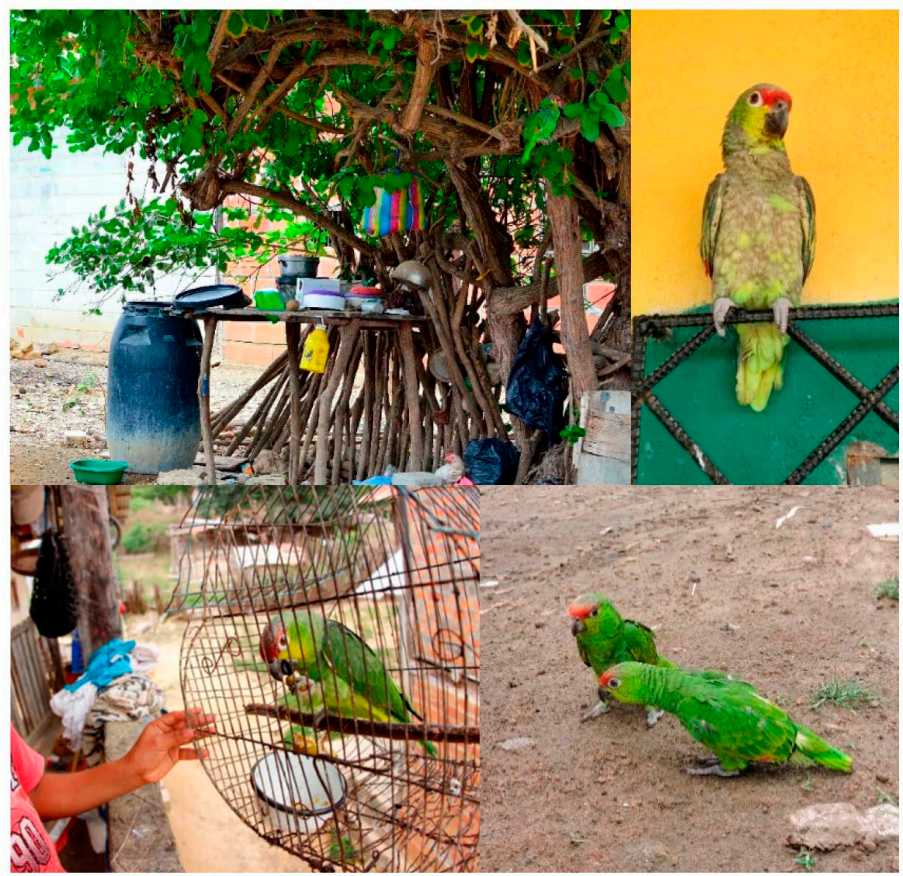

Figure 2. Examples of pet Lilacine Amazons in four rural communities in coastal Ecuador. Parrots were kept in a variety of situations; indoors or outdoors, caged or with clipped wings. In some cases pet parrots that were housed in gardens were not initially considered to be captive by the owner, but for the purposes of this study any parrot living in the locality of people was classed as a pet.

Table 2. The number of communities in which each of the 19 species was reported as a pet and the range size within the study area according to BirdLife International [24].

\begin{tabular}{|c|c|c|}
\hline Parrot Species (Year of Update) & $\begin{array}{l}\text { Range within Study Area } \\
\text { SA }\left(\mathrm{km}^{2}\right)\end{array}$ & $\begin{array}{c}\text { Number of Communities Reporting the } \\
\text { Species (Out of 65) }\end{array}$ \\
\hline Lilacine or Ecuadorian Amazon Amazona lilacina (2018) & 38,860 & 20 \\
\hline Grey-cheeked Parakeet Brotogeris pyrrhoptera (2014) & 8645 & 20 \\
\hline Red-masked Parakeet Psittacara erythrogenys (2007) & 54,327 & 17 \\
\hline Pacific Parrotlet Forpus coelestis (2017) & 55,300 & 8 \\
\hline Red-lored Amazon Amazona autumnalis (2017) & 5583 & 6 \\
\hline Blue-headed Parrot Pionus menstruus (2013) & 27,943 & 2 \\
\hline Southern Mealy Amazon Amazona farinosa (2013) & 8612 & 1 \\
\hline Bronze-winged Parrot Pionus chalcopterus (2014) & 46,508 & 1 \\
\hline White-winged Parakeet Brotogeris versicolurus (2018) & 549 & 1 \\
\hline Chestnut-fronted Macaw Ara severus (2014) & 49,329 & 0 \\
\hline Blue-fronted Parrotlet Touit dilectissimus (2014) & 13,470 & 0 \\
\hline White-capped Parrot Pionus seniloides (2012) & 1482 & 0 \\
\hline Rose-faced Parrot Pyrilia pulchra (2002) & 12,828 & 0 \\
\hline Great Green Macaw Ara ambiguus (2014) & 3899 & 0 \\
\hline Red-faced Parrot Hapalopsittaca pyrrhops (2000) & 49 & 0 \\
\hline Cordilleran Parakeet Psittacara frontatus (2014) & 1347 & 0 \\
\hline Barred Parakeet Bolborhynchus lineola (2014) & 2183 & 0 \\
\hline Red-billed Parrot Pionus sordidus (2014) & 1565 & 0 \\
\hline El Oro Parakeet Pyrrhura orcesi (1999) & 615 & 0 \\
\hline \multicolumn{3}{|c|}{ Kept by communities but non-native } \\
\hline Orange-winged Amazon Amazona amazonica & NA & 1 \\
\hline Yellow-crowned Amazon Amazona ochrocephala & NA & 5 \\
\hline
\end{tabular}




\subsection{Predicted Distribution of Pet Parrots}

The locations of the 43 communities with pet parrots and the 20 communities with pet Lilacines were reduced to 42 and 19, respectively, after limiting each group of locations to one per $1 \mathrm{~km}$. A total of 3803 background points were randomly allocated. The mean AUC of resulting models was $0.69 \pm 0.06$ (sd) for pet parrots and $0.62 \pm 0.20$ (sd) for pet Lilacines. The most important variables predicting the presence of pet parrots were distance to nearest road (permutation importance, $\mathrm{PI}=40 \%$ ) and distance to nearest town (PI $=28 \%)$; the key factors for the presence of pet Lilacines were the mean annual NDVI $(\mathrm{PI}=33 \%)$ and species value, representing the native distribution $(\mathrm{PI}=27 \%)($ Table 3$)$. Predictions show that pet parrots are likely to be widespread throughout the study area, whereas pet Lilacines seem to be more likely within the species range. Both models show a high probability of occurrence of pets to the west of Guayaquil and out towards the coast (Figure 3).

Table 3. Permutation importance values for variables used to create models predicting the distribution of pet parrots and pet Lilacines in coastal Ecuador.

\begin{tabular}{ccc}
\hline \multirow{2}{*}{ Variable } & \multicolumn{2}{c}{ Permutation Importance (\%) } \\
\cline { 2 - 3 } & Pet Parrot Model & Pet Lilacine Model \\
\hline Mean annual NDVI & 11 & 33 \\
\hline Distance to road & 40 & 1 \\
\hline Human population density & 18 & 23 \\
\hline Distance to town & 28 & 27 \\
\hline Species value & 3 &
\end{tabular}

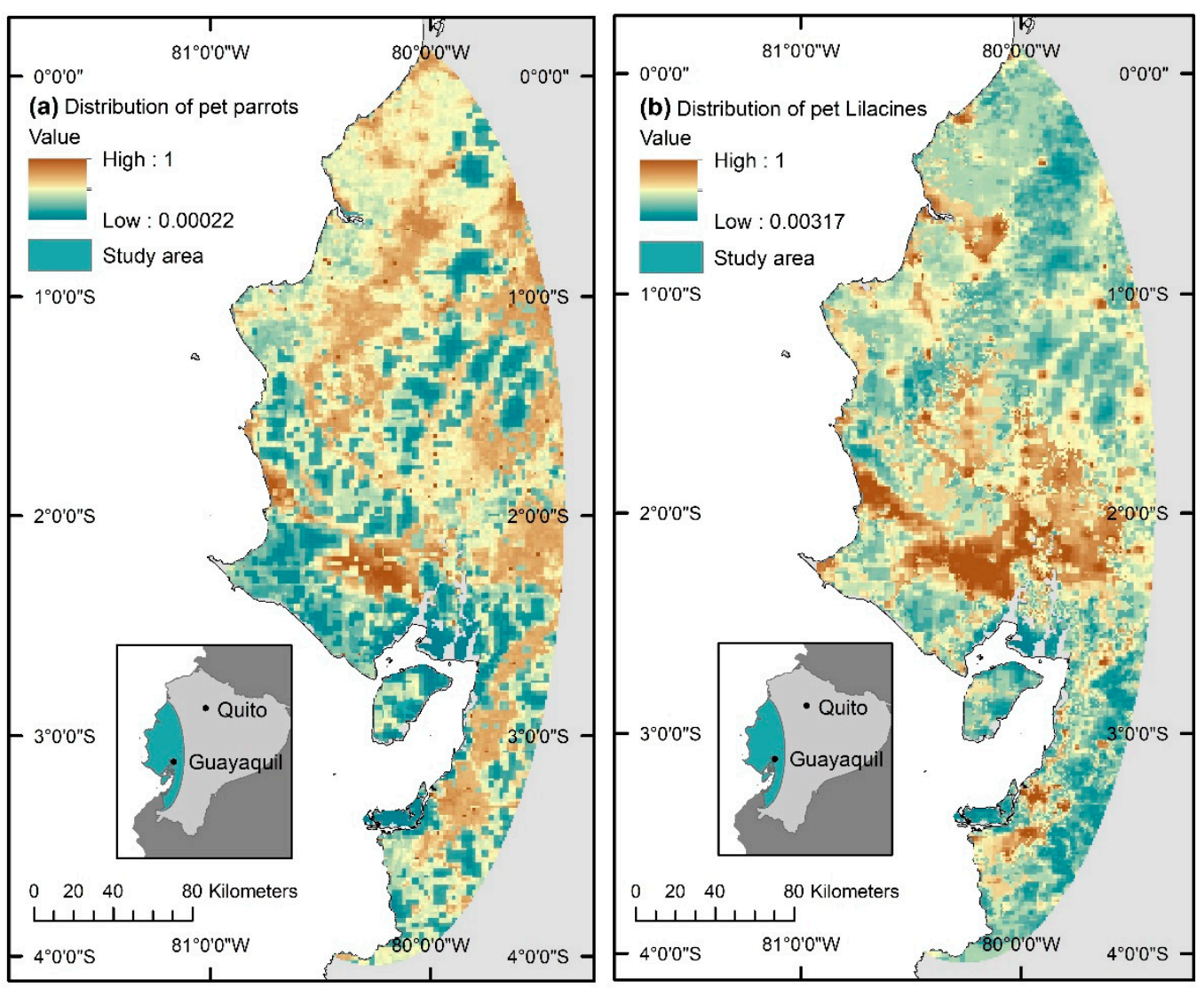

Figure 3. Model predictions showing the distribution of pet parrots (a) and pet Lilacines (b). 


\subsection{Incidence of Parrot Ownership and Trapping}

Within 12 selected communities where pet parrots occur, 106 (96 men/10 women) participants ( $\min 6, \max 13$, mean 8.8 per community) took part in interviews. All participants worked outdoors as farmers (57), fishers (25), crab fishers (18), bee keepers (3) or wildlife guides (3). Participants were familiar with A. lilacina, the majority seeing them daily $(68 \%)$, weekly $(19 \%)$, or monthly $(8 \%)$, with the remaining $5 \%$ just a few times per year. Of all participants, $66 \%(70)$ had owned a pet parrot either previously or currently, and $36 \%(38)$ a pet Lilacine. The majority $(74 \%, 28)$ of Lilacine pets had been caught by the owner themselves, with the remainder received as gifts $(16 \%, 6)$, bought $(2 \%, 6)$, or found $(2 \%, 6)$. In the last three years, 15 people have owned a total of 24 Lilacines. In total, 34 people $(32 \%)$ confirmed that they had previously captured Lilacines, the majority $(76 \%, 26)$ to keep as a pet themselves, the others to sell $(9 \%, 26)$ or for undisclosed reasons $(15 \%, 5)$. Pet ownership and trapping varied between community clusters, with the highest rates of historic and current ownership and trapping of Lilacine Amazons occurring in the crab fishing communities (D) in the southern part of the range (Table 4).

Table 4. The number, age and occupations of people interviewed from each community cluster and the number who reported owning parrots or catching parrots, either previously or in the last three years.

\begin{tabular}{|c|c|c|c|c|c|c|c|c|c|c|c|}
\hline \multirow{2}{*}{$\begin{array}{l}\text { Community } \\
\text { Cluster }\end{array}$} & \multirow{2}{*}{$\mathbf{n}$} & \multirow{2}{*}{$\begin{array}{l}\text { Mean Age } \\
\text { (Years) }\end{array}$} & \multicolumn{4}{|c|}{$\begin{array}{l}\text { Occupation: Farmer (F), Fisher (Fi), } \\
\text { Crab Fisher }(C F), \text { Other }(\mathrm{O})\end{array}$} & \multicolumn{3}{|c|}{ In Life Time: } & \multicolumn{2}{|c|}{$\begin{array}{c}\text { In the Last Three } \\
\text { Years: }\end{array}$} \\
\hline & & & $\mathbf{F}$ & $\mathbf{F i}$ & CF & $\mathbf{O}$ & $\begin{array}{c}\text { Owned } \\
\text { Parrot }\end{array}$ & $\begin{array}{l}\text { Owned } \\
\text { Lilacine }\end{array}$ & $\begin{array}{l}\text { Caught } \\
\text { Lilacine }\end{array}$ & $\begin{array}{l}\text { Owned } \\
\text { Lilacine }\end{array}$ & $\begin{array}{l}\text { Caught } \\
\text { Lilacine }\end{array}$ \\
\hline $\mathrm{A}$ & 31 & 53 & 8 & 19 & 1 & 3 & 23 & 11 & 9 & 0 & 0 \\
\hline B & 23 & 48 & 23 & 0 & 0 & 0 & 11 & 8 & 8 & 4 & 3 \\
\hline $\mathrm{C}$ & 29 & 53 & 26 & 0 & 0 & 3 & 18 & 4 & 4 & 1 & 1 \\
\hline $\mathrm{D}$ & 23 & 46 & 0 & 6 & 17 & 0 & 18 & 15 & 13 & 10 & 6 \\
\hline Total & 106 & 50 & 57 & 25 & 18 & 6 & 70 & 38 & 34 & 15 & 10 \\
\hline
\end{tabular}

In the last three years, 10 interviewees reported that they had caught Lilacines, with at least 16 birds among them, to either keep the bird as a pet (7), to sell it (1), or for an undisclosed reason (2). All had either no or primary level schooling, and were men 23-72 years old. They reported seeing wild Lilacines daily (9) or weekly (1), and all but one believed the wild population was stable or increasing. In cases where the capture location was given, this always corresponded to the person's occupation, i.e., farmers reported catching parrots in the forest, fishers and crab fishers reported trapping parrots in mangroves (Table 5). Seven of the 10 people who had caught Lilacines in the last three years reported that multiple other people within their community also catch Lilacines, and all 10 knew of multiple pet Lilacines in their community (mean 5.2 Lilacines).

Table 5. The age, gender, schooling, and occupation of all interviewees who reported catching Lilacines in the last three years. We report the trapping location, reason for capture and how many were caught.

\begin{tabular}{|c|c|c|c|c|c|c|c|}
\hline $\begin{array}{l}\text { Community } \\
\text { Cluster }\end{array}$ & $\begin{array}{c}\text { Age } \\
\text { (Years) }\end{array}$ & Gender & Level of Schooling & Occupation & Location of Capture & Reason for Capture & $\begin{array}{c}\text { Number of Lilacines Caught } \\
\text { in Last Three Years }\end{array}$ \\
\hline \multirow{3}{*}{ B } & 41 & Male & Primary & Farmer & Dry forest & Pet & 1 \\
\hline & 23 & Male & Primary & Farmer & Dry forest & Pet & 1 \\
\hline & 72 & Male & Primary & Farmer & Dry forest & Pet & 1 \\
\hline $\mathrm{C}$ & 68 & Male & None & Farmer & Undisclosed & Undisclosed & 1 \\
\hline \multirow{6}{*}{$\mathrm{D}$} & 32 & Male & Primary & Crab fisher & Mangrove & Pet & 2 \\
\hline & 54 & Male & Primary & Crab fisher & Mangrove & Pet & 1 \\
\hline & 40 & Male & Primary & Crab fisher & Mangrove & Pet & 1 \\
\hline & 47 & Male & Primary & Crab fisher & Undisclosed & Undisclosed & Unknown \\
\hline & 51 & Male & Primary & Fisher & Mangrove & Pet & 1 \\
\hline & 67 & Male & None & Fisher & Mangrove & Sell & 7 \\
\hline
\end{tabular}




\subsection{Attitudes towards Parrot Ownership and Trapping}

Across all communities, responses to attitude statements show a strong feeling that wild parrots are important for nature and participants indicated that local people have a responsibility to protect the environment. This is mirrored by a strong feeling of discomfort with outsiders coming to catch parrots and with parrots disappearing from their area. On the contrary, $46 \%$ of all participants believe it is OK to catch wild parrots to sell and $32 \%$ that it is acceptable to keep a pet parrot. Furthermore, $17 \%$ of people did not believe that catching wild parrots could make them become extinct in the local area (Figure 4). There were no significant differences between communities in the distribution of positive, neutral and negative responses to all attitude statements apart from one: "I think it is OK to keep a parrot as a pet". For this, there was a significant difference between mean responses of the community groups $(\mathrm{H}=6.613, p=0.022)$, with $52 \%$ of community cluster $\mathrm{D}$ believing this is acceptable, and just $20 \%$ of cluster A believing so.

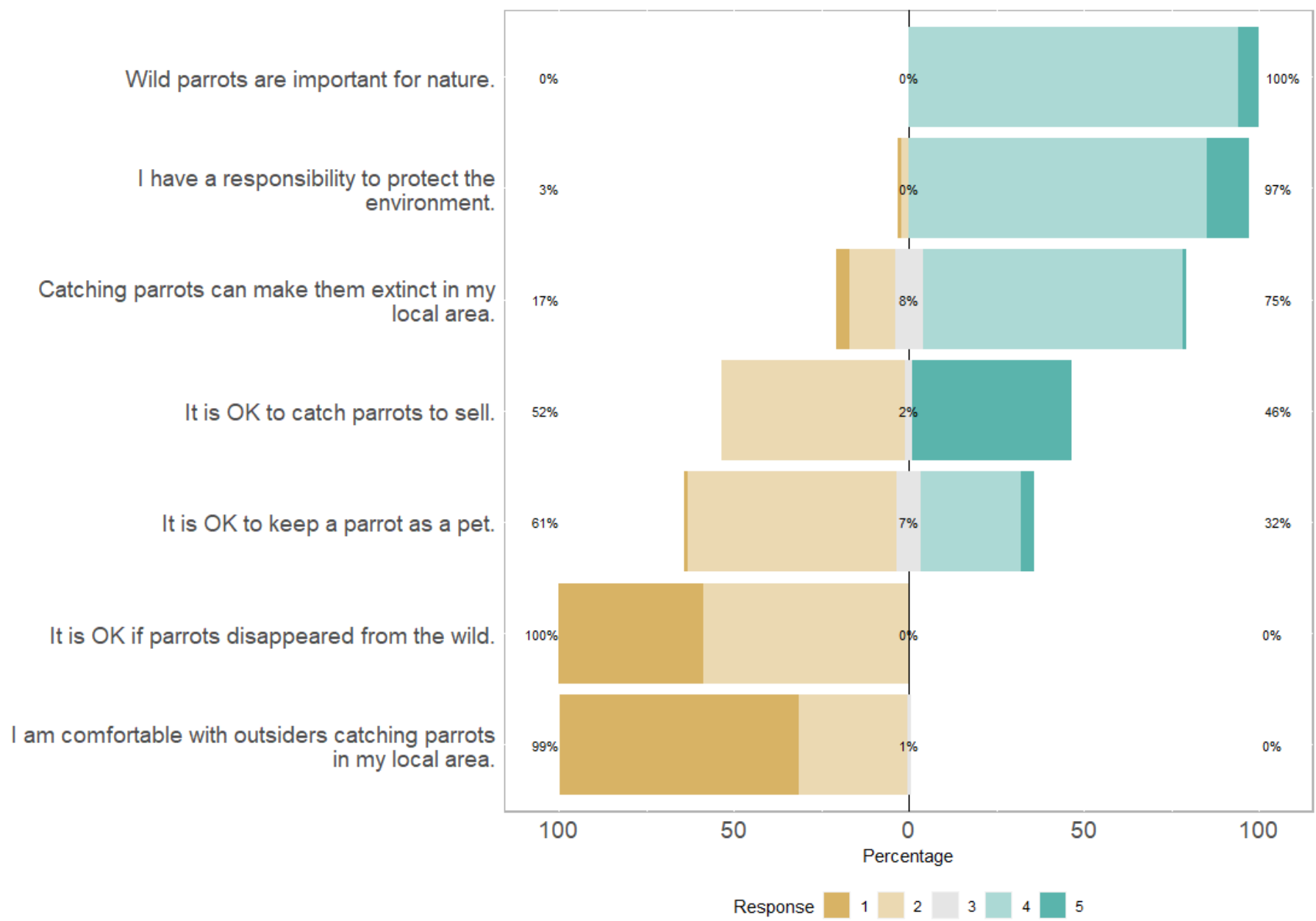

Figure 4. Responses to attitude statements are reported on a five point Likert scale $(1=$ strongly disagree, $2=$ disagree, $3=$ neutral, $4=$ agree, $5=$ strongly agree).

\subsection{Trapping Pressure Index}

When combining our results into a trapping pressure index, we can see variation between the four community clusters, with higher values suggesting a higher risk to the wild Lilacine Amazon population in that area (Table 6). Wild Lilacines occurring around community cluster D are at greatest risk, due to the high level of reported parrot ownership and capture, and a strong local attitude that this is acceptable. Those occurring around community cluster $\mathrm{C}$ are also at high risk, as model predictions here show a high 
probability of pet Lilacine occurrence (0.78), which suggests a high probability of trapping as pet owners mostly report catching their pet themselves. The wild population occurring around community cluster A appears to be at the lowest risk from trapping, as there were no reports here of current Lilacine ownership or capture; however, this is the smallest remaining subpopulation of the species within its range, which could also explain the low prevalence of pets. When considered against participants' responses to their perceived status of the wild population locally, we see more negative responses from the southern community clusters, with the most frequent response in cluster $\mathrm{C}$ being 'decreasing' $(76 \%)$, in cluster D 'stable' (39\%), whilst 'increasing' in cluster B (83\%) and A (42\%).

Table 6. Trapping pressure index for each community cluster, calculated by adding together factors of predicted or reported level of pet ownership and trapping, and attitudes towards pet keeping, capture and trade. Predicted probabilities were converted into percentages for this calculation.

\begin{tabular}{|c|c|c|c|c|}
\hline \multirow{2}{*}{ Trapping Pressure Factor } & \multicolumn{4}{|c|}{ Community Cluster } \\
\hline & A & B & $\mathrm{C}$ & D \\
\hline Mean probability of predicted parrot ownership $(0-1)$ & 0.47 & 0.35 & 0.70 & 0.36 \\
\hline Mean probability of predicted Lilacine ownership (0-1) & 0.51 & 0.59 & 0.78 & 0.19 \\
\hline Percentage of participants who owned pet Lilacines in the last three years & 0 & 17 & 3 & 43 \\
\hline Percentage of participants who caught Lilacines in last three years & 0 & 13 & 3 & 26 \\
\hline Percentage of participants believing it is OK to keep a pet parrot & 20 & 23 & 37 & 52 \\
\hline Percentage of participants believing it is OK to catch wild parrots to sell & 39 & 32 & 41 & 74 \\
\hline Overall trapping pressure index (rank) & $157(4)$ & $179(3)$ & $232(2)$ & $250(1)$ \\
\hline
\end{tabular}

\section{Discussion}

This study found that $66 \%$ of rural coastal communities in Ecuador have pet parrots and $31 \%$ have pet Lilacine Amazons A. lilacina. Within these communities, $66 \%$ of people had owed a pet parrot during their lifetime, and $14 \%$ currently owned Lilacines. This is similar to Costa Rica, where $18 \%$ of households owned a pet parrot in 2001 [9]. Our current ownership questions focused on just one species, so we expect the level of current ownership of all parrot species to be much higher and similar to Colombia where $58 \%$ of all people had pet parrots [10]. Current ownership and reports of Lilacine trapping in the last three years varied between communities, with $0 \%$ to $50 \%$ and $0 \%$ to $26 \%$, respectively. Ten participants confirmed that they had taken Lilacines from the wild in the last three years to keep birds as pets, or to sell them, so we suggest that, similarly to Yellow-shouldered Amazon Amazona barbadensis harvesting in Venezuela, there are at least two categories of trappers-"poacher-keepers" and "poacher-sellers" [35], with only the latter having the contacts and logistics to sell birds. People in occupations with an established and frequent trade link-for example, fishers or crab fishers-may have more opportunity to transport trapped birds to other towns to sell. We also found that capture location corresponded to the occupation of the poacher, which may explain the variation between rural communities as occupation depends heavily on location, i.e., in-land or coastal. Our trapping pressure index identified that the southern distribution of the species is likely to be at greatest risk, which agrees with earlier work showing a vast population decline in this area [17] and provides further evidence that this area should be prioritised for conservation support.

Understanding whether taking parrots from the wild is opportunistic or selective is important because selective capture can lead to the extinction of species through overharvesting [10]. Our results suggest that trapping is selective given the differences in the popularity of species, with some kept in 20 communities and some in none. The two most frequently reported pet parrot species differed greatly in body mass, which, in general, is linked to longevity in captivity [36], suggesting that variation in popularity is not a side effect of survival rates in captivity. Similarly to previous research, we have noted a preference for Amazon parrots, with all three wild occurring species and two non-native species being kept as pets [8]. However, parrot ownership and capture, at least within 
rural communities, may also be opportunistic. Most parrot owners had caught their bird locally, within areas they visit during a normal days' work, and our predictions showed that pet Lilacines were more likely within the species' wild distribution. Moreover, parrot species kept as pets had a larger average wild range size than those that are not. This all suggests that ownership and capture are driven in part by parrot availability and accessibility [11], but more research including a true measure of wild parrot abundance, and surveys and interviews in larger towns and cities are needed. According to anecdotal reports in some rural communities, orders are placed by outsiders from cities such as Guayaquil or Quito, which fits the typical multi-level chain involving trappers, middlemen and markets described by Pires [37] and needs investigation.

Our interviews revealed that Lilacine Amazons were trapped both in mangroves, where they roost, and dry forests, where they feed and nest [38,39], suggesting that both adults and chicks are being taken from the wild. Anecdotal reports from communities suggest past events of outsiders casting nets over mangrove islands to remove an entire roost of Lilacines at a time. Research has shown that the removal of adults from a population can have more drastic consequences on population size and growth rate, than removal of chicks [40]. In a study of illegal wildlife trade markets in Bolivia, contrary to the idea that most parrots come from nest poaching, $70 \%$ of parrots were adults [41]. Our results also suggest that $60 \%$ of Lilacines caught in the last three years were from mangroves, so are likely to be adult or juvenile birds. A number of studies have shown that anti-poaching efforts, in the form of additional human presence, can benefit bird populations [42-44] and that recruitment of young people (who may be facilitators in parrot trapping) from the local community to act as nest monitors, can significantly decrease poaching rate [45]. In some cases, nest protection implemented at the correct time of year can have a significant effect [42], but we suggest that year-round protection is needed to safeguard both vulnerable roosting and nesting sites for this species.

The lack of environmental education in Ecuadorian schools is a barrier to reducing parrot ownership and capture [16]. The main purpose of any environmental education strategy is to change people's knowledge and attitudes, and ultimately behaviours [46]. Alone, or in combination with other conservation interventions, environmental education projects can result in a decrease in the persecution of parrots and consequently an increase in population size [43,47]. Most people in our study believed that wild parrots were important for nature and that they themselves had a responsibility to protect parrots. Local people do not want parrots to disappear and are strongly opposed to outsiders coming in to their community to catch them. Contrastingly, up to $74 \%$ per community agreed that it was $\mathrm{OK}$ to take parrots from the wild to sell, and up to $52 \%$ believed that it was OK to keep them as a pet. Furthermore, up to $30 \%$ disagreed that catching parrots could make them locally extinct. We found similarity between attitudes and reported behaviours. In areas with more pet Lilacines and reports of parrot trapping, there was also a stronger belief that this was acceptable, compared to areas with fewer pets and trapping. This suggests that changing these attitudes could have an impact on future behaviour, and that the implementation of a targeted behaviour change education project could have conservation benefits to the Lilacine Amazon. We suggest following the practices of the successful PRIDE campaigns [48] which inspire people to take pride in the species and habitats that make their communities so unique, whilst introducing viable alternatives to environmentally destructive practices.

We therefore recommend that a combination of environmental education to change attitudes towards parrot ownership and trapping, and increased protection of wild birds through nest and roost guarding, particularly in the southern part of its range, are conservation priorities for the Lilacine Amazon.

Author Contributions: Conceptualization, R.B., M.J., M.P. and S.M.; Data curation, R.B. and I.S.-P.; Formal analysis, R.B.; Funding acquisition, R.B. and M.P.; Investigation, R.B. and I.S.-P.; Methodology, R.B., M.J. and S.M.; Project administration, R.B.; Resources, R.B. and M.P.; Supervision, M.J. and S.M.; 
Visualization, R.B.; Writing—original draft, R.B.; Writing—review and editing, R.B., M.J. and S.M. All authors have read and agreed to the published version of the manuscript.

Funding: This research was funded by the North of England Zoological Society.

Institutional Review Board Statement: The study was approved virtually by The North of England Zoological Society Ethical Review Committee, on Friday 17 November 2017.

Informed Consent Statement: Informed consent was obtained from all subjects involved in the study.

Data Availability Statement: The data presented in this study are available on request from the corresponding author. The data are not publicly available due to anonymity and sensitive content.

Acknowledgments: We would like to extend our thanks to the Amazona Lilacina Education Project volunteers who assisted us with community surveys and interviews. This study would not have been possible without the support of local communities and we thank every person who volunteered their time, valuable knowledge and personal experiences to this research. Thank you to Paolo Escobar for providing one of the pet parrot photographs and to three reviewers for their constructive comments.

Conflicts of Interest: The authors declare no conflict of interest.

\section{References}

1. Olah, G.; Butchart, S.H.M.; Symes, A.; Guzmán, I.M.; Cunningham, R.; Brightsmith, D.J.; Heinsohn, R. Ecological and socioeconomic factors affecting extinction risk in parrots. Biodivers. Conserv. 2016, 25, 205-223. [CrossRef]

2. Wright, T.F.; Toft, C.A.; Enkerlin-Hoeflich, E.; Gonzalez-Elizondo, J.; Albornoz, M.; Rodríguez-Ferraro, A.; Rojas-Suárez, F.; Sanz, V.; Trujillo, A.; Beissinger, S.R.; et al. Nest Poaching in Neotropical Parrots. Conserv. Biol. 2001, 15, 710-720. [CrossRef]

3. Dahlin, C.R.; Blake, C.; Rising, J.; Wright, T.F. Long-term monitoring of Yellow-naped Amazons (Amazona auropalliata) in Costa Rica: Breeding biology, duetting, and the negative impact of poaching. J. Field Ornithol. 2018, 89, 1-10. [CrossRef]

4. Berkunsky, I.; Quillfeldt, P.; Brightsmith, D.; Abbud, M.; Aguilar, J.; Alemán-Zelaya, U.; Aramburú, R.; Arias, A.A.; McNab, R.B.; Balsby, T.; et al. Current threats faced by Neotropical parrot populations. Biol. Conserv. 2017, 214, 278-287. [CrossRef]

5. Bush, E.R.; Baker, S.E.; Macdonald, D.W. Global Trade in Exotic Pets 2006-2012. Conserv. Biol. 2014, 28, 663-676. [CrossRef]

6. Ecuador's Wildlife Trade. Available online: https://www.researchgate.net/profile/Pablo-Sinovas/publication/312600490_ Ecuador_s_Wildlife_Trade/links/5885fbd04585150dde4a8016/Ecuador-s-Wildlife-Trade.pdf (accessed on 1 July 2020).

7. Clarke, R.V.; De By, R.A. Poaching, habitat loss and the decline of neotropical parrots: A comparative spatial analysis. J. Exp. Criminol. 2013, 9, 333-353. [CrossRef]

8. Tella, J.L.; Hiraldo, F. Illegal and Legal Parrot Trade Shows a Long-Term, Cross-Cultural Preference for the Most Attractive Species Increasing Their Risk of Extinction. PLoS ONE 2014, 9, e107546. [CrossRef] [PubMed]

9. Drews, C. Wild Animals and Other Pets Kept in Costa Rican Households: Incidence, Species and Numbers. Soc. Anim. 2001, 9, 107-126. [CrossRef]

10. Romero-Vidal, P.; Hiraldo, F.; Rosseto, F.; Blanco, G.; Carrete, M.; Tella, J.L. Opportunistic or Non-Random Wildlife Crime? Attractiveness rather than Abundance in the Wild Leads to Selective Parrot Poaching. Diversity 2020, 12, 314. [CrossRef]

11. Pires, S.; Clarke, R.V. Are Parrots CRAVED? An Analysis of Parrot Poaching in Mexico. J. Res. Crime Delinq. 2011, 49, 122-146. [CrossRef]

12. Harrison, R.D.; Sreekar, R.; Brodie, J.F.; Brook, S.; Luskin, M.; O'Kelly, H.; Rao, M.; Scheffers, B.; Velho, N. Impacts of hunting on tropical forests in Southeast Asia. Conserv. Biol. 2016, 30, 972-981. [CrossRef] [PubMed]

13. Benítez-López, A.; Alkemade, R.; Schipper, A.M.; Ingram, D.J.; A Verweij, P.; Eikelboom, J.; Huijbregts, M.A.J. The impact of hunting on tropical mammal and bird populations. Science 2017, 356, 180-183. [CrossRef]

14. John, F.A.V.S.; Edwards-Jones, G.; Jones, J.P.G. Conservation and human behaviour: Lessons from social psychology. Wildl. Res. 2010, 37, 658-667. [CrossRef]

15. Ecuadorian National Assembly. Article 3: Crimes against Wild Fauna. Comprehensive Organic Criminal Code in the Classification of Crimes against Wild Flora and Fauna. 2017. Available online: https://observatoriolegislativo.ec/media/archivos_leyes/ Contra_de_la_Flora_y_Fauna_Tr._305545.pdf (accessed on 11 December 2020).

16. Ortiz-von Halle, B. Bird's-Eye View: Lessons from 50 Years of Bird Trade Regulation \& Conservation in Amazon Countries; TRAFFIC: Cambridge, UK, 2018; p. 198.

17. Biddle, R.; Ponce, I.S.; Cun, P.; Tollington, S.; Jones, M.; Marsden, S.; Devenish, C.; Horstman, E.; Berg, K.; Pilgrim, M. Conservation status of the recently described Ecuadorian Amazon parrot Amazona lilacina. Bird Conserv. Int. 2020, 30, 586-598. [CrossRef]

18. Athanas, N.; Greenfield, P.J. Birds of Western Ecuador: A Photographic Guide; Princeton University Press: Princeton, NJ, USA, 2016.

19. Mideros, M.A. Ecuador: Defining and measuring multidimensional poverty, 2006-2010. CEPAL Rev. 2012, 2012, 49-67. [CrossRef]

20. Dodson, C.H.; Gentry, A.H. Biological Extinction in Western Ecuador. Ann. Mo. Bot. Gard. 1991, 78, 273. [CrossRef]

21. Cuesta, F.; Peralvo, M.; Merino-Viteri, A.; Bustamante, M.; Baquero, F.; Freile, J.F.; Muriel, P.; Torres-Carvajal, O. Priority areas for biodiversity conservation in mainland Ecuador. Neotrop. Biodivers. 2017, 3, 93-106. [CrossRef] 
22. BirdLife International. Amazona Lilacina. IUCN Red List Threat. Species 2020, e.T22728296A181432250. Available online: https:/ / dx.doi.org/10.2305/IUCN.UK.2020-3.RLTS.T22728296A181432250.en (accessed on 16 December 2020).

23. IUCN. Significant Trade in Wildlife: A Review of Selected Species in CITES Appendix II-Volume 3 Birds; IUCN Conservation Monitoring Centre: Cambridge, UK, 1988; pp. 36-41.

24. BirdLife International and Handbook of the Birds of the World (2020) Bird Species Distribution Maps of the World. Version 2020.1. Available online: http:/ / datazone.birdlife.org/species/requestdis (accessed on 31 July 2020).

25. ArcGIS Desktop, Environmental Systems Research Institute. Available online: https://www.esri.com/en-us/arcgis/products/ arcgis-desktop/resources (accessed on 1 November 2020).

26. R Core Team. R: A Language and Environment for Statistical Computing; R Core Team: Vienna, Austria, 2020.

27. Phillips, S.J.; Anderson, R.P.; Schapire, R.E. Maximum entropy modeling of species geographic distributions. Ecol. Model. 2006 190, 231-259. [CrossRef]

28. Biddle, R.; Solis-Ponce, I.; Jones, M.; Marsden, S.; Pilgrim, M.; Devenish, C. Assessing the value of local community knowledge in species distribution modelling for a threatened Neotropical parrot. Biodivers. Conserv. 2020, in press.

29. Sorichetta, A.; Hornby, G.M.; Stevens, F.R.; Gaughan, A.E.; Linard, C.; Tatem, A.J. High-resolution gridded population datasets for Latin America and the Caribbean in 2010, 2015, and 2020. Sci. Data 2015, 2, 150045. [CrossRef]

30. OpenStreetMap Foundation, OSMF. OpenStreetMap. Available online: https://www.openstreetmap.org/copyright (accessed on 1 November 2019).

31. Aiello-Lammens, M.E.; Boria, R.A.; Radosavljevic, A.; Vilela, B.; Anderson, R.P. spThin: An R package for spatial thinning of species occurrence records for use in ecological niche models. Ecography 2015, 38, 541-545. [CrossRef]

32. Zuur, A.F.; Ieno, E.N.; Walker, N.; Saveliev, A.A.; Smith, G.M. Mixed Effects Models and Extensions in Ecology with R; Springer: New York, NY, USA, 2009.

33. Wisz, M.S.; Hijmans, R.J.; Elith, J.; Peterson, A.T.; Graham, C.H.; Guisan, A.; NCEAS Predicting Species Distributions Working Group. Effects of sample size on the performance of species distribution models. Divers. Distrib. 2008, 14, 763-773. [CrossRef]

34. Package 'likert'. Available online: https:// cran.r-project.org/web/packages/likert/likert.pdf (accessed on 15 September 2020).

35. Sanchez-Mercado, A.; Blanco, O.; Sucre-Smith, B.; Briceño-Linares, J.M.; Peláez, C.; Rodriguez, J.P.; Sucre-Smith, B. Using Peoples' Perceptions to Improve Conservation Programs: The Yellow-Shouldered Amazon in Venuzuela. Diversity 2020, 12, 342. [CrossRef]

36. Brouwer, K.; Jones, M.L.; King, C.E.; Schifter, H. Longevity records for Psittaciformes in captivity. Int. Zoo Yearb. 2000, 37, 299-316. [CrossRef]

37. Pires, S.F. The illegal parrot trade: A literature review. Glob. Crime 2012, 13, 176-190. [CrossRef]

38. Berg, K.S.; Angel, R.R. Seasonal roosts of Red-lored Amazons in Ecuador provide information about population size and structure. J. Field Ornithol. 2006, 77, 95-103. [CrossRef]

39. Dupin, M.K.; Dahlin, C.R.; Wright, T.F. Range-Wide Population Assessment of the Endangered Yellow-Naped Amazon (Amazona auropalliata). Diversity 2020, 12, 377. [CrossRef]

40. Valle, S.; Collar, N.J.; Harris, W.E.; Marsden, S. Trapping method and quota observance are pivotal to population stability in a harvested parrot. Biol. Conserv. 2018, 217, 428-436. [CrossRef]

41. Pires, S.F.; Schneider, J.L.; Herrera, M.; Tella, J.L. Spatial, temporal and age sources of variation in parrot poaching in Bolivia. Bird Conserv. Int. 2015, 26, 293-306. [CrossRef]

42. A González, J. Harvesting, local trade, and conservation of parrots in the Northeastern Peruvian Amazon. Biol. Conserv. 2003, 114, 437-446. [CrossRef]

43. Vaughan, C.L.; Nemeth, N.M.; Cary, J.; Temple, S. Response of a Scarlet Macaw Ara macao population to conservation practices in Costa Rica. Bird Conserv. Int. 2005, 15, 119-130. [CrossRef]

44. Granadeiro, J.P.; Dias, M.P.; Rebelo, R.; Santos, C.D.; Catry, P. Numbers and Population Trends of Cory's Shearwater Calonectris diomedea at Selvagem Grande, Northeast Atlantic. Waterbirds 2006, 29, 56-60. [CrossRef]

45. Briceño-Linares, J.M.; Rodríguez, J.P.; Rodríguez-Clark, K.M.; Rojas-Suárez, F.; Millán, P.A.; Vittori, E.G.; Carrasco-Muñoz, M. Adapting to changing poaching intensity of yellow-shouldered parrot (Amazona barbadensis) nestlings in Margarita Island, Venezuela. Biol. Conserv. 2011, 144, 1188-1193. [CrossRef]

46. Jacobson, S.K.; McDuff, M.D.; Monroe, M.C. Conservation Education and Outreach Techniques; Oxford University Press: Oxford, UK, 2015.

47. Sanz, V.; Grajal, A. Successful Reintroduction of Captive-Raised Yellow-Shouldered Amazon Parrots on Margarita Island, Venezuela. Conserv. Biol. 2008, 12, 430-441. [CrossRef]

48. The Principles of Pride. Available online: https://www.rare.org/wp-content/uploads/2019/02/Rare-Principles-of-Pride.pdf (accessed on 15 October 2020). 